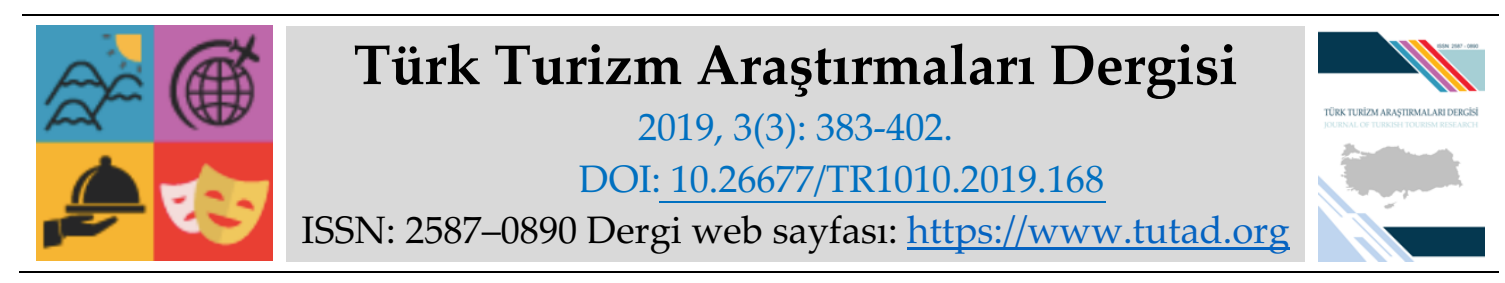

ARASTTIRMA MAKALESI

\title{
Sosyal Medyada Gelişmeleri Kaçırma Korkusunun Kişinin Tatil Satın Alma Niyetine Etkisi
}

Öğr. Gör. Filiz Özlem ÇETiNKAYA, Kırşehir Ahi Evran Üniversitesi, Çiçekdağı MYO, Kırşehir, e-posta:filyozum@gmail.com

ORCID: https://orcid.org/0000-0002-2509-8011

Prof. Dr. Ramazan Pars ŞAHBAZ, Ankara Hacı Bayram Veli Üniversitesi, Turizm Fakültesi, Ankara, e-posta:pars.sahbaz@hbv.edu.tr

ORCID: https://orcid.org/0000-0002-7946-6625

Öz

Sosyal medyada gelişmeleri kaçırma korkusu; kişinin ilgisini çekmesine rağmen kendi dışında gerçekleşen olaylara dahil olamama ve bunlardan sosyal medya aracilığıyla haberdar olma durumunda yaşadığı bir duygu değişimi şeklinde ifade edilebilir. Günümüze kadar yapılan çalışmalarda, sosyal medya ve gelişmeleri kaçırma korkusu arasındaki ilişkinin turizm faaliyetlerine etkisine dair bir araştırmaya rastlanılamaması nedeniyle bu çalışmanın amacı sosyal medyada gelişmeleri kaçırma korkusunun kişinin tatil satın alma niyetine etkisini ortaya koymaktır. Bu amaçla doğrudan/dolaylı olarak gelir elde eden 18 yaş üzerindeki bireylerden, Google formlar aracilığıyla toplanan 1623 anket analize tabi tutulmuştur. Anket formunda; katılımcıların sosyal medya kullanım yoğunluklarını, gelişmeleri kaçırma korkusu düzeylerini, satın alma niyetlerini ölçen, katılımcıların demografik özellikleri hakkında tanımlayıcı sorular içeren ifadeler yer almaktadır. Araştırma sonucunda sosyal medya kullanım yoğunluğu ile gelişmeleri kaçırma korkusu arasında anlamlı bir ilişki bulunmakla birlikte sosyal medyada gelişmeleri kaçırma korkusunun kişinin tatil satın alma niyetine etkisi olduğu sonucuna da ulaşılmıştır. Elde edilen sonuçlar ve literatür taraması ışığında, araştırmacılara ve işletmelere çeşitli önermelerde bulunulmuştur.

Anahtar Kelimeler: Sosyal Medya Bağımlılığı, Gelişmeleri Kaçırma Korkusu, Satın Alma Niyeti, Turistik Tüketici Davranışı, Turizm.

Makale Gönderme Tarihi: 25.04.2019

Makale Kabul Tarihi: 08.07.2019

\section{Önerilen Atıf:}

Çetinkaya, F. Ö. ve Şahbaz, R. P. (2019). Sosyal Medyada Gelişmeleri Kaçırma Korkusunun Kişinin Tatil Satın Alma Niyetine Etkisi, Türk Turizm Araştırmaları Dergisi, 3(3): 383-402.

(c) 2019 Türk Turizm Araştırmaları Dergisi. 


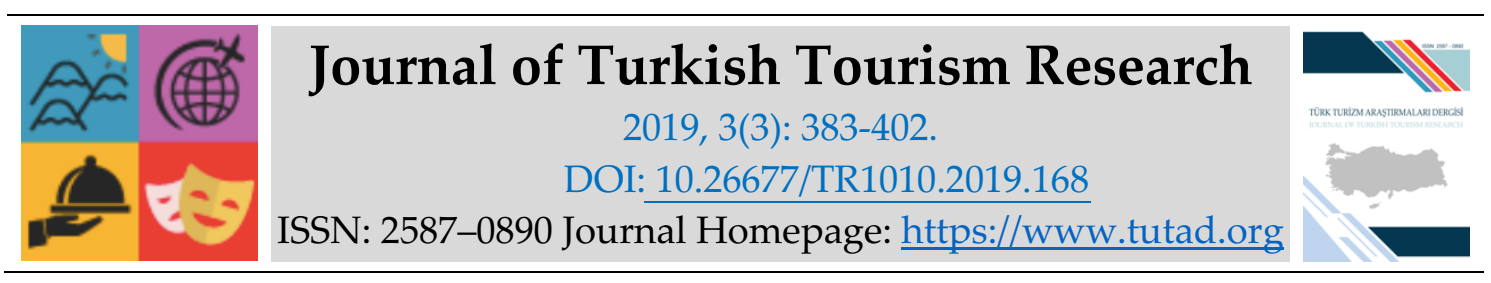

\title{
RESEARCH PAPER
}

\section{The Effect of FoMO on the Intention of Buying a Holiday on Social Media}

Lecturer Filiz Özlem ÇETINKAYA, Kırşehir Ahi Evran University, Çiçekdağı Vocational High

School, Kırşehir, e-mail: filyozum@gmail.com

ORCID: https://orcid.org/0000-0002-2509-8011

Prof. Dr. Ramazan Pars ŞAHBAZ, Ankara Hacı Bayram Veli Üniversitesi, Faculty of Tourism, Ankara, e-mail:pars.sahbaz@hbv.edu.tr

ORCID: https://orcid.org/0000-0002-7946-6625

\begin{abstract}
Fear of Missing Out in social media can be expressed as a feeling of emotion in the case of not being involved in the events taking place outside of him and being aware of them through social media (although it may attract the attention of the person). In the studies carried out to date, the aim of this study is to reveal the effect of FoMO (Fear of Missing Out) on holiday buying intention in social media due to the lack of research on the effect of the relationship between social media and FoMO on tourism activities. For this purpose, individuals who are over 18 years of age have been subject to 1623 questionnaires collected through Google forms. In the questionnaire; the participants' expressions about the social media usage intensities, FoMO levels, purchasing intentions, and the descriptive questions about the demographic characteristics of the participants. As a result of the research, although there is a significant relationship between the intensity of social media usage and FoMO, it was concluded that FoMO has an effect on the purchase intention of the person in social media. In the light of the results and literature review, various propositions have been made to researchers and enterprises.
\end{abstract}

Keywords: Social Media Addiction, FoMO, Purchase Intention, Touristic Consumer Behavior, Tourism.

Received: 25.04 .2019

Accepted: 08.07.2019

\section{Suggested Citation:}

Çetinkaya, F. Ö. and Şahbaz, R. P. (2019). The Effect of FoMO on the Intention of Buying a Holiday on Social Media, Journal of Turkish Tourism Research, 3(3): 383-402.

(C) 2019 Türk Turizm Araştırmaları Dergisi. 


\section{Gíriş}

Sosyal medya, toplumun yapısı üzerinde etkisi büyük olan, etkileşim kalıplarını (anlık ve interaktif iletişime imkân veren) büyük ölçüde değiştiren önemli bir kavramdır (Asur ve Huberman, 2010). Sosyal medya siteleri, Gelişmeleri Kaçırma Korkusu (GKK) kavramı üzerinde önemli bir rol oynamaktadır. GKK, iletişim kanallarının olduğu her yerde görülmesine rağmen, günümüzde diğer insanların neler yaptığını, ne söylediğini bilmek ihtiyacı ve isteği sosyal medyanın bu kavram üzerindeki etkisini diğer iletişim kanallarına nazaran daha da artırmıştır. Bunun yanı sıra bilginin her zamankinden daha kolay erişilebilir olması da insanları sosyal medya aracılığıyla bilgi tüketmeye bağımlı hale getirmiş, bireyler çoğu zaman mobil cihazları ile tek tuşla girebildikleri ve edinebildikleri bilgiye fazlasıyla ihtiyaç duymaya, eksikliğinde de GKK hissetmeye başlamışlardır. Bu kavramların birbiriyle bu kadar ilişki içerisinde olması araştırmacıların da önemle üzerinde durdukları: "Sosyal medya bağımlılığı (sosyal medya kullanım yoğunluğu), GKK'nin nedeni midir, sonucu mudur ya da her iki kavram da birbirinin tetikleyicisi midir, ruhsal sıkıntı yaşayan bireylerin sosyal medyayı daha az kullanmaları GKK kavramını daha da tetikler mi?" sorularını gündeme getirmektedir (Abel vd., 2016).

Araştırmanın temel problemini açıklayabilmek için söz konusu çalışmanın neden yapıldığ 1 ve ilgili yazında hangi boşluğu dolduracağı ya da ilgili yazına ne şekilde katkı sağlayacağının net bir şekilde ortaya konulması gerekmektedir. Literatür incelendiğinde, çalışmada bahsedilen değişkenler ile ilgili tek başına ya da birden fazla değişkeni aynı anda inceleyen birçok farklı çalışmaya rastlanılmıştır (Alalwan, 2018; Alt, 2018; Argan ve Tokay Argan, 2018; Aydın, 2018; Casale vd., 2018; Classen, 2018; Dhir vd., 2018; Elhai vd., 2018; Osatuyi ve Turel, 2018; Tien vd., 2018; Blachnio, vd., 2017; Blackwell vd., 2017; Yin vd., 2017; Al-Menayes, 2016; Beyens, vd. 2016; Hodkinson, 2016; Gil vd., 2015; Doster, 2013). Buna rağmen, bu çalışmanın konusu olan değişkenler (Sosyal Medya, GKK, Satın Alma Niyeti) arasındaki ilişkiyi bir arada inceleyen herhangi bir çalışmaya Türkçe ve yabancı literatürde daha önce rastlanılamaması, çalışmanın yapılmasının temel gereksinimi olarak görülmektedir. Başka bir deyiş ile turizm sektöründe, sosyal medyada GKK'nin kişinin tatil satın alma niyeti üzerindeki etkisini belirlemeye yönelik daha önce yapılan bir çalışmaya rastlanılamamıştır. Böylece bu araştırmanın yapılmasına gerek duyularak, yapılan çalışma ile birlikte; turizm literatüründeki boşluğun doldurulması amacının yanı sıra, pazarlama ve psikoloji literatürüne de katkı sağlanacağı düşünülmektedir. Buradan yola çıkılarak araştırmanın problemi; "Sosyal medyadaki GKK'nin kişinin tatil satın alma niyeti üzerine etkisi var mıdır?" şeklinde oluşturulmuştur.

\section{SOSYAL MEDYA KULLANIM YOĞUNLUĞU, GELIŞMELERİ KAÇIRMA KORKUSU VE SATIN ALMA NIYYETI KAVRAMLARININ İLIŞKİSI}

Bilgisayar teknolojilerindeki gelişmeler ışığında toplumsal paylaşım ağları hızla yaygınlaşmaya başlamış ve kullanıcı sayısı da oldukça artmıştır. Bireyler bu ağları kullanarak yeni insanlarla karşılaşma, iletişime geçme ve mevcut olanlarla da iletişimde kalmayı devam ettirme amacını gütmektedirler (Toprak vd., 2009:28). Bu türden gereksinimleri yerine getiren sosyal ağlar; sosyal medya uygulamalarını araç olarak kullanmaktadırlar.

Sosyal medya ağı için tam bir tanım yapılamaz. Birçok benzer web sitesi sosyal medya olarak adlandırılmakta, kimilerince ise sosyal bir ağ olarak tanımlanmaktadır. Ancak bu sosyal ağlar da (örneğin; Facebook) sosyal medya aracı olarak kullanılabilmektedir. Sosyal medya "insanların fikir ve deneyimlerini paylaştığı bir platformdur" şeklinde tanımlanabilir (Baban, 2012:72).

Polat'a (2016:21) göre sosyal medya; “haber, içerik ve bilgiyi paylaşma, okuma ve keşfetme alışkanlıklarının değişmesidir" olarak yorumlanırken, Boyd ve Ellison'a (2008) göre ise, sınırlı bir 
sistem içerisinde kamu ya da yarı kamu bir profil oluşturmayı sağlayan, bağlantıda oldukları kişilerin listesinin açıç̧a belirtildiği ve diğer kişilerin sisteminde bağlantıda oldukları kişilerin listesinin görüntülenmesine olanak tanıyan web tabanlı bir servis olarak adlandırılmaktadır.

Sosyal medyanın her geçen gün kullanımının artması yeni kavramların da ortaya çıkmasına neden olmuştur. Bunlardan birisi de bireylerin sosyal medyada bir şeyler kaçırma, diğerlerinden haberdar olamama korkusuyla sosyal medyada daha fazla zaman harcamalarına neden olan bir bağımlılık türü şeklinde ifade edilen "Gelişmeleri Kaçırma Korkusu” dur (FoMO-Fear of Missing Out) (Przybylski vd., 2013).

Temel ihtiyaç memnuniyeti düzeyi düşük olan bireyler; başkalarıyla temas kurmak, sosyal yetkinliği geliştirmek ve sosyal bağları derinleştirmek için bir fırsat olarak algıladıkları sosyal medya kullanımına doğrudan yönelebilirler. Bireylerin temel ihtiyaçlarının tatmin düzeyleri ve sosyal medya arasındaki ilişki aynı zamanda dolaylı olarak da kendisini gösterebilir. Başka bir deyişle Gelişmeleri Kaçırma Korkusu (GKK) ile bağlantılı olabilir. Bireylerin sosyal medyadaki GKK, onların sosyal medyaya bağımlı hale gelmelerine neden olur (Przybylski vd., 2013).

Yüksek düzeyde GKK'ye sahip olan bireyler, sosyal medyayı daha fazla kullanarak sosyal ihtiyaçlarını gidermeye çalışmaktadırlar (Wolniewicz vd., 2018). Bazı araştırmalar sorunlu (aşırı) internet kullanımı seviyeleri ile GKK arasındaki ilişkinin küçük ve orta düzeyde etkilerini ortaya koyarken (Stead ve Bibby, 2017; Wolniewicz vd., 2018) bazıları da GKK'nin kişilerin daha düşük algıladıkları yaşam kalitesi ve olumsuz duygular, sosyal katılım ve sorunlu internet kullanımı/sorunlu akıllı telefon kullanımı ile ilişkili olduğu yönünde sonuçlar ortaya koymuştur (Elhai vd., 2018).

GKK, bireylerin sosyal medyayı yoğun bir şekilde kullanmalarında önemli bir rol oynamaktadır (Swar ve Hameed, 2017). Przybylski vd.'nin (2013) yaptığı çalışmada sosyal medya kullanım yoğunluğu yüksek olan bireylerin GKK eğilimlerinin de yüksek olduğundan bahsedilmektedir. Başka bir ifade ile GKK ve sosyal medya kullanım yoğunlukları birbirleriyle doğru orantılıdır. Biri artış gösterdiğinde diğerinin de artış göstermesi kaçınılmaz olmaktadır.

Buna göre; $H_{1}$ hipotezi: "Sosyal medya kullanımı ile GKK arasında anlamlı bir ilişki vardır" şeklinde kurulmuştur.

GKK hakkında yapılan tüm bu çalışmalara göre; GKK'nin sosyal medyayı takip etme isteğini tetiklemesi ile; GKK akıllı telefonların aşırı kullanımına neden olmaktadır (Elhai vd., 2018; Wolniewicz vd, 2018). Diğer cihazlar aracılığıyla da ulaşılan sosyal medyada sürekli çevrimiçi olma arzusu nedeniyle; başkalarını takipte kalma ve onlardan habersiz kalabilecek olma düşüncesi ile; GKK'nin anksiyete (Elhai vd., 2018; Blackwell vd., 2017; Oberst vd., 2017; Elhai vd., 2016; Wang vd., 2012), dikkat dağınıklı̆̆ı ve depresif davranışlara daha fazla eğilimli olmaya (Elhai vd., 2018; Baker vd., 2016; Elhai vd., 2016; Wang vd., 2012) neden olabileceği de ifade edilebilir. Bunların yanı sıra; birçok araç vasıtası ile (telefon, tablet, bilgisayar) uzun süre sosyal medyayı takip etme sonucunda GKK'nin fizyolojik olarak; sırt, baş, bel, boyun, vb. ağrilara da neden olabileceği düşünülmektedir.

İnternet, tüketiciler için, diğer birçok bilgi kaynağından daha fazla ve çeşitli bilgi almayı sağlamaktadır. Sosyal medya sayesinde, tüketiciler artık yalnızca internet üzerindeki içeriklere erişmekle kalmayıp, kendi içeriklerini oluşturup (sanal topluluklar, bloglar, vb.) paylaşabilmektedirler. Turizm için de özellikle tüketicilere kendi seyahat programlarını yapma, web siteleri aracılığıyla turizm paketlerini satın alma imkânlarını sunarak, tüketicinin aktif katılımına izin veren teknolojiler önem kazanmaktadır (Gretzel vd., 2011). Yapılan bir çalışmada (Zhao vd., 2015) otellerin internet üzerinden çevrimiçi araştırılması ile kişilerin satın alma niyetleri arasında pozitif bir ilişki bulunmuştur. 
Sosyal medya, seyahat planlama üzerinde büyük bir etkiye sahiptir. Özellikle diğer kişilerin çevrimiçi paylaşımları ve yorumlarına bakarak, çevrimiçi seyahat planlama süreci kişilerin önemli bir aktivitesi haline gelmiştir. Akıllı telefon bağımlılığının da artışına bağlı olarak, istenilen her an ve her yerde internete ulaşılmasıyla, seyahat edecek olanların araştırma yapması ve davranışlarını planlamalarında sosyal medyanın etkisi daha da artmıştır (Xiang vd., 2015; Xiang vd., 2014).

Buna göre; $H_{3}$ hipotezi: "Sosyal medya kullanımı kişinin tatil satın alma niyeti üzerinde etkilidir" şeklinde kurulmuştur.

Sosyal medya ve buna bağlı olarak gelişen birçok olgu (Örneğin GKK), günümüzde birçok alanı etkisi altına almaya başlamıştır. Bunlardan birisi de pazarlamanın bir dalı olan satın alma davranışıdır.

GKK genellikle kişilerin bir şeyler satın almalarını sağlar. Örneğin; komşununkinden daha büyük bir televizyon ya da arkadaşlarla birlikte geçirilecek bir tatil. Çünkü hepsi gidiyordur ve kişi bunu kaçırmaktan korkar. Her iki durumda da insanlar sosyal baskılar ve döngüden çıkma ya da dışlanmış olma korkusuna göre hareket eder. Bu durumda çoğu insan GKK'ye teslim olur (Dykman, 2012).

Buna göre; $H_{4}$ hipotezi: “GKK kişinin tatil satın alma niyeti üzerinde etkilidir" şeklinde kurulmuştur.

Argan vd. (2018), GKK'nin yalnızca sosyal medya ile ilgili olmayıp, pazarlama ve tüketici davranışı ile de çok yakından bir ilgisi olduğunu ortaya çıkarmaya çalışan ve bunu GKK tüketici olarak adlandıran kuramsal bir yaklaşımı ele almışlardır. Çalışma sonucunda karar verme süreci öncesinde, karar verme süreci esnasında ve sonrasında GKK tüketicilerin geleneksel tüketicilerden nasıl farklılıklar gösterebildiğini ortaya koymaya çalışmışlardır.

Buna göre; $H_{2}$ hipotezi: "Sosyal medya kullanımı ile GKK arasındaki ilişki kişinin tatil satın alma niyeti üzerinde etkilidir" şeklinde kurulmuştur.

$\mathrm{Bu}$ araştırmada; sosyal medyadaki GKK'nin kişinin tatil satın alma niyetine etkisinin ortaya konması amaçlanmıştır. Çalışmanın bir diğer amacı, sosyal medya kullanım yoğunluğu ile GKK arasındaki ilişkinin derecesini belirlemektir. Ayrıca, bu çalışma ile birlikte turizm alanı için yeni olduğu ifade edilebilecek bir konunun araştırılması ve sonraki çalışmalar için örnek teşkil edeceği varsayılmaktadır.

\section{YÖNTEM}

Bu çalışma "sosyal medyada GKK'nin kişinin tatil satın alma niyetine etkisi"nin belirlenmesi amacını taşımaktadır. Bu doğrultuda hazırlanan çalışma, nicel yöntemler uygulanan betimsel ve açımlayıcı bir araştırma niteliğindedir. 


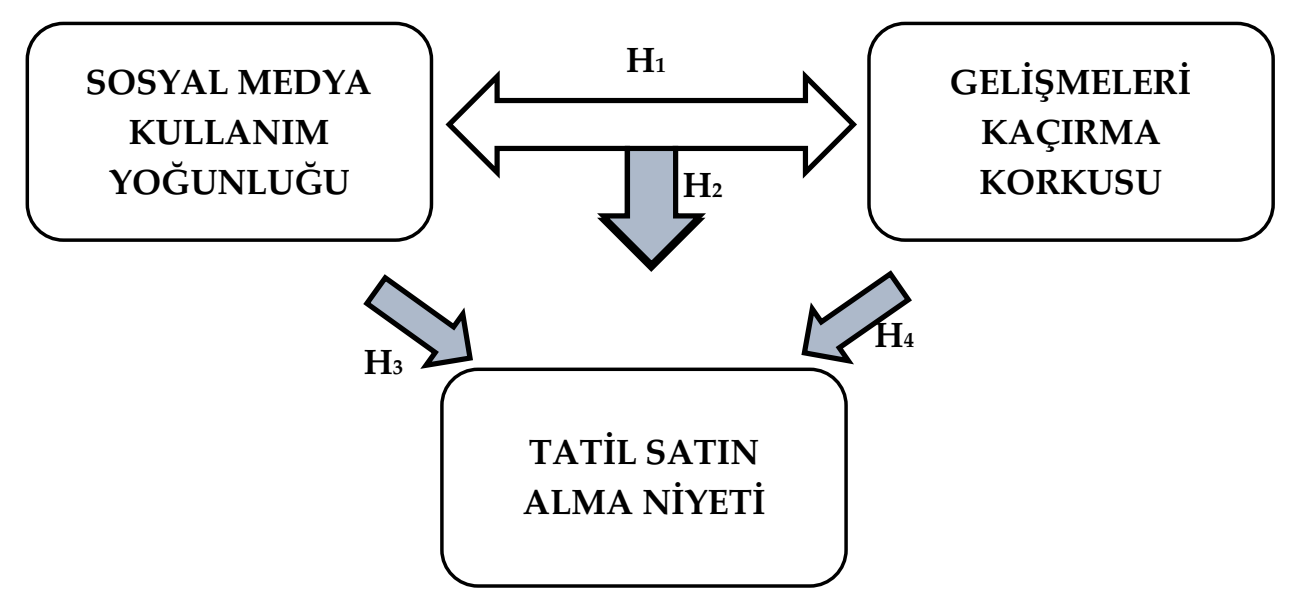

Şekil 1. Varsayılan Araştırma Modeli

\section{Araştırmanın Evren ve Örneklemi}

Çalışmanın evrenini 18 yaş ve üzeri sosyal medya kullanıcıları oluşturmaktadır. Çalışmanın örneklemini ise, doğrudan/dolaylı gelir elde eden 18 yaş üzerindeki sosyal medya kullanıcıları oluşturmaktadır. Google formlarda oluşturulan anketin bağlantı adresi sosyal medya ve e-posta üzerinden katılımcılara ulaştırılmıştır. 1931 katılımcıya ulaşılmış olup bunların 308 tanesi sosyal medya kullanmadıkları için analiz dışı bırakılarak 1623 tanesi analize uygun bulunmuştur. Bu katılım sayısı bir kısıt olarak alınırken, araştırma sonuçları ancak uygulanılan örneklemi temsil yeteneğine sahiptir.

\section{Verilerin Toplanması ve Ölçekler}

Araştırmada verilerin toplanmasında anket formundan yararlanılmıştır. Soru formu 4 bölümden oluşmakta olup; birinci bölüm demografik ve tanımlayıcı bilgileri içermektedir. İkinci bölümde sosyal medya kullanım yoğunluğu, üçüncü bölümde GKK, dördüncü bölümde ise satın alma niyeti ile ilgili ifadeler yer almaktadır. Araştırmada "Sosyal Medya Bağımlılığı (SMB) ÖlçeğiYetişkin Formu" (Şahin ve Yağcl, 2017), "GKK" ölçeği (Przybylski vd., 2013) ve "Satın Alma Niyeti Ölçeği" (Pavlou ve Gefen, 2004)'nden faydalanılmıştır. İfadeler 5'li Likert şeklinde olup 1: Kesinlikle Katılmıyorum - 5: Kesinlikle Katılıyorum aralığındadır.

Anket, daha fazla katılımcıya ulaşabilmek ve sosyal medya kullanıcılarının da kolaylıkla erişebilmesi amaciyla sosyal medya ortamlarında (Facebook, Instagram, Twitter, vb.) paylaşılmıştır. Anket verileri 16.12.2018-14.02.2019 tarihleri arasında toplanmıştır.

Bu araştırmada veriler toplanırken kolayda örnekleme yöntemi kullanılmıştır. Bu yöntemin esası, örnekleme, anketi cevaplayan herkesin dâhil edilmesidir. Böylece ulaşılabilen ve isteyen herkes anketi doldurabilecektir (Coşkun vd., 2015:142).

\section{Araştırmada Kullanılan Ölçeklerin Güvenilirlik Analizi}

Bu araştırmada kullanılan yirmi sorudan oluşan SMB ölçeği, on sorudan oluşan GKK ölçeği ve üç sorudan oluşan Satın Alma Niyeti ölçeklerinin güvenirliklerini ölçmek için alfa katsayısı kullanılmıştır. 
Tablo 1. Güvenirlik Analizi Sonuçları

\begin{tabular}{lc}
\hline Ölçek & Alpha Katsayısı $(\boldsymbol{\alpha}=)$ \\
\hline SMB &, 869 \\
\hline GKK &, 861 \\
\hline Satın Alma Niyeti &, 826 \\
\hline
\end{tabular}

Alpha katsayılarına bakıldığında, bu araştırmada yer alan SMB, GKK ve Satın Alma Niyeti ölçeğinin oldukça güvenilir olduğu gözlemlenmiştir.

\section{Ölçeklerin Geçerliliklerine İlişkin Analizler}

Ölçeklerin yapı geçerliliğini ölçmek amacıyla açımlayıcı faktör analizi uygulanmıştır.

Tablo 2. KMO ve Bartlett Testi Sonuçları

\begin{tabular}{lcrrr}
\hline & KMO & Bartlett testi & df & \multicolumn{1}{c}{ Sig. } \\
\cline { 2 - 5 } SMB ölçeği &, 926 & 10978,495 & 190 &, 000 \\
\hline GKK ölçeği &, 852 & 7433,738 & 45 &, 000 \\
\hline Satın Alma Niyeti ölçeği &, 684 & 1984,026 & 3 &, 000 \\
\hline
\end{tabular}

Tablo 2'de görüldüğü gibi SMB ölçeği $(0,926)$, GKK ölçeği $(0,852)$ ve Satın Alma Niyeti ölçeği $(0,684)$ KMO değerlerinin 0,60 ' dan yüksek olması sebebiyle faktör analizine uygun bulunmuştur. Bartlett testi sonuçları incelendiğinde ise 0,01 düzeyinde manidar olduğu görülmüş olup verilerin çok değişkenli normal dağılımdan geldiği kabul edilmiştir.

\section{Verilerin Analizi}

Araştırmada elde edilen verilerin analizinde değişik istatistiksel yöntemler kullanılmıştır. Verilerin parametrik test koşullarını sağlayıp sağlamadı̆̆ının değerlendirilmesi yapılmıştır (Faktör analizi/ güvenirlik/ normal dağılım). Demografik ve kişisel bilgilerin analizinde tanımlayıcı istatistikler (yüzde, frekans, ortalama) kullanılırken, değişkenler arasında gözlenebilen ve gözlenemeyen değişkenlerin nedensel ve ilişkisel bir şekilde test edilebilmesi için korelasyon, basit doğrusal regresyon, çoklu regresyon ve univariate varyans (Anova) analizlerinden faydalanılmıştır.

\section{BULGULAR}

Çalışmanın amacı doğrultusunda sorulan demografik ve tanımlayıcı soruların neticesinde elde edilen verilere ilişkin bulgular ve yorumlara aşağıda yer verilmiştir.

Tablo 3'e göre araştırmaya katılanların \%58'i kadın ve \%42'si erkektir. Katılımcıların \%3'ü 18 yaş, \%75'i 19-38 yaş, \%18'i 39-53 yaş, \%4'ü 54-72 yaş ve \%0'1 73 yaş ve üstüdür. Araştırmaya katılanların \%2'si (24 kişi) ilköğretim, \%11'i (181 kişi) lise, \%18'i (284 kişi) önlisans, \%49'u (803 kişi) lisans ve \%20'i (331 kişi) lisansüstü eğitim düzeyindedir. Analiz sonucuna göre katılımcıların çoğunun lisan mezunu olduğu görülmektedir. 
Analiz sonucuna göre katılımcıların çoğunun bayan olduğu (\%58,3), çoğunlukla (\%74,6) 19-38 yaşlarında oldukları, çoğunun $(\% 52,8)$ bekar olduğu ve çoğunlukla $(\% 60,2)$ çocuklarının olmadığı görülmektedir.

Tablo 3. Katılımcıların Cinsiyet, Yaş, Medeni Durum ve Çocuk Sayılarına İlişkin Bilgiler

\begin{tabular}{lcc}
\hline Cinsiyet & $\mathbf{( N )}$ & $\mathbf{( \% )}$ \\
\hline Kadın & 947 & $\mathbf{5 8 , 3}$ \\
\hline Erkek & 676 & 41,7 \\
\hline Yaş & 45 & 2,8 \\
\hline 18 & 1210 & $\mathbf{7 4 , 6}$ \\
\hline $19-38$ & 293 & 18,1 \\
\hline $39-53$ & 72 & 4,4 \\
\hline $54-72$ & 3 & 0,2 \\
\hline 73 ve üstü & $\mathbf{( N )}$ & $\mathbf{( \% )}$ \\
\hline Ö̆grenim düzeyi & 24 & 1,5 \\
\hline Ilköğretim & 181 & 11,2 \\
\hline Lise & 284 & 17,5 \\
\hline Önlisans & 803 & $\mathbf{4 9 , 5}$ \\
\hline Lisans & 331 & 20,4 \\
\hline Lisansüstü & 1623 & 100,0 \\
\hline Toplam & &
\end{tabular}

Araştırmaya Katılan Katılımcıların Sosyal Medya Kullanım Yoğunlukları, Gelişmeleri Kaçırma Korkusu ve Tatil Satın Alma Niyeti Algılamaları Arasındaki İlişkinin Değerlendirilmesi

Araştırmaya katılanların sosyal medya kullanım yoğunlukları, GKK ve tatil satın alma niyeti algılamaları arasındaki ilişkileri ortaya koymak amacıyla korelasyon analizi yapılmışıı. Yapılan analize ait tablo aşağıda verilmiştir.

Tablo 4. Araştırmaya Katılan Katılımcıların Sosyal Medya Kullanım Yoğunlukları, Gelişmeleri Kaçırma Korkusu ve Tatil Satın Alma Niyeti Algılamaları Arasındaki İlişkinin Değerlendirilmesine Yönelik Korelasyon Tablosu

\begin{tabular}{lccc}
\hline & $\begin{array}{c}\text { Sosyal Medya } \\
\text { Kullanımı }\end{array}$ & $\begin{array}{c}\text { Gelişmeleri Kaçırma } \\
\text { Korkusu }\end{array}$ & $\begin{array}{c}\text { Tatil Satın } \\
\text { Alma Niyeti }\end{array}$ \\
\hline $\begin{array}{l}\text { Sosyal Medya } \\
\text { Kullanımı }\end{array}$ & 1 & & \\
\hline $\begin{array}{l}\text { Gelişmeleri Kaçırma } \\
\text { Korkusu }\end{array}$ & $\mathbf{0 , 6 3 3 ^ { * * }}$ & 1 & \\
\hline Tatil Satın Alma Niyeti & $0,208^{* *}$ & $0,257^{* *}$ & 1 \\
\hline${ }^{* *}<0,01$ anlamlılık düzeyinde (iki yönlü) & &
\end{tabular}


Tablo 4'teki verilere göre sosyal medya kullanımı ile GKK arasında pozitif yönlü anlamlı bir ilişki vardır $(\mathrm{p}<0,01, \mathrm{R}=0,633)$. Başka bir ifade ile sosyal medya kullanımı arttıkça GKK de artmaktadır. Bu bakış açısından yola çıkılarak $\mathrm{H}_{1}$ : "Sosyal medya kullanımı ile GKK arasında anlamlı bir ilişki vardır" hipotezi kabul edilmiştir. Ayrıca "Sosyal medya kullanımı ile tatil satın alma niyeti" arasında ( $p<0,01, R=0,208)$ ve "GKK ile tatil satın alma niyeti" arasında $(p<0,01, R=0,257)$ da "sosyal medya kullanımı ile GKK" arasındaki ilişki kadar güçlü $(R=0,633)$ olmasa da pozitif yönlü anlamlı bir ilişki olduğu görülmektedir.

Literatürde yapılmış bazı çalışmalarda (Swar ve Hameed, 2017; Baker vd., 2016; Michot vd., 2015; Przybylski vd., 2013) olduğu gibi bu sonuca göre de sosyal medya kullanım yoğunluğu ile GKK arasında anlamlı bir ilişki olduğu görülmektedir. Bunun nedeninin GKK yaşayan bireylerin daha fazla sosyal medyada zaman geçirmek istemeleri ya da sosyal medyayı yoğun olarak takip eden kişilerin GKK'yi daha fazla yaşadıkları söylenebilir.

\section{Sosyal Medya Kullanımı ve Gelişmeleri Kaçırma Korkusu Bağımsız, Tatil Satın Alma Niyeti Bağımlı Değişken Olmak Üzere Doğrusal Regresyon Analizi}

Araştırmaya katılanların sosyal medya kullanım yoğunlukları ile GKK arasındaki ilişkinin tatil satın alma niyeti üzerindeki etkisini ortaya koymak amaciyla basit doğrusal regresyon analizi yapılmıştır. Yapılan analize ait tablo aşağıda verilmiştir.

Tablo 5. Sosyal Medya Kullanımı ile GKK'nin Kişinin Tatil Satın Alma Niyeti Üzerindeki Etkisine Ait Regresyon Analizi

\begin{tabular}{ccccc}
\hline Model & $\mathbf{R}$ & $\mathbf{R}^{2}$ & Düzeltilmiş $\mathbf{R}^{2}$ & Tahmini Hata \\
\hline 1 & $0,257^{\mathrm{a}}$ & 0,066 & 0,065 & 1,18132 \\
\hline 2 & $0,263^{\mathrm{b}}$ & 0,069 & 0,068 & 1,17950 \\
\hline
\end{tabular}

a. Sabit: GKK

b. Sabit: GKK, Sosyal Medya Kullanımı

Sosyal medya kullanımı ile GKK'nin kişinin tatil satın alma niyeti üzerine etkisini ortaya koymak için yapılan çoklu regresyon analizi sonucunda (bkz. Tablo 5), ilk model sadece GKK ile satın alma niyeti arasındaki ilişkiyi, 2. model sosyal medya kullanımı ile GKK'nin, kişinin tatil satın alma niyeti üzerindeki etkisini göstermektedir. İlk model (GKK) varyansın \%25,7'sini açılarken, sosyal medya kullanımı da eklendiğinde \%26,3'ünü açıklamaktadır $(\mathrm{p}<0,01)$. Bu sonuçtan yola çıkılarak sosyal medya kullanımı değişkeninin, GKK'nin tatil satın alma niyeti üzerindeki etkisini artırdığ yorumu yapılabilir. Bu bakış açısından yola çıkılarak $\mathrm{H}_{2}$ : "Sosyal medya kullanımı ile GKK arasındaki ilişki kişinin tatil satın alma niyeti üzerinde etkilidir" hipotezi kabul edilmiştir.

İnsanlar sosyal baskılardan ya da dışlanmış olma korkusundan, dolayısıyla sosyal medyada yaşadıkları GKK' den uzaklaşmak amacıyla satın alma davranışı gösterirler (Dykman, 2012). Bu araştırmanın sonucuna göre de sosyal medya kullanım yoğunluğu ile GKK arasındaki ilişkinin, kişinin tatil satın alma niyeti üzerinde etkili olduğu, bunun nedeninin de sosyal medyada GKK yaşayan kişilerin, diğerlerinin yaptıklarını yapmayı isteme duygusundan kaynaklandığı söylenebilir. 


\section{Sosyal Medya Kullanımı Bağımsız, Tatil Satın Alma Niyeti Bağımlı Değişken Olmak Üzere Doğrusal Regresyon Analizi}

Araştırmaya katılanların sosyal medya kullanım yoğunluğunun tatil satın alma niyeti üzerindeki etkisini ortaya koymak amacıyla basit doğrusal regresyon analizi yapılmıştır. Yapılan analize ait tablo aşağıda verilmiştir.

Tablo 6. Tatil Satın Alma Niyetinin Sosyal Medya Kullanımına Göre Yordanmasına İlişkin Regresyon Analizi Sonuçları

\begin{tabular}{ccccc}
\hline Model & $\mathbf{R}$ & $\mathbf{R}^{2}$ & Düzeltilmiş $\mathbf{R}^{2}$ & Tahmini Hata \\
\hline 1 & $0,208^{a}$ & 0,043 & 0,043 & 1,19555 \\
\hline
\end{tabular}

a. Sabit Değişken: Sosyal Medya Kullanımı

Tablo 6'ya göre sosyal medya kullanımı ile tatil satın alma niyeti değişkenleri arasında pozitif yönlü anlamlı bir ilişki $(R=0,208)$ vardır. Ayrıca belirlilik katsayısı $R^{2}=0,043$ olarak hesaplanmış olup tatil satın alma niyetinin \%43'ünün sosyal medya kullanımına bağlı olduğu söylenebilir $(\mathrm{p}<0,01)$.

Tablo 7. Sosyal Medya Kullanımı ile Kişinin Tatil Satın Alma Niyeti Arasındaki İlişkinin Derecesini Gösteren Varyans (Anova) Analizi

\begin{tabular}{lcccccc}
\hline \multicolumn{1}{l}{ Model } & $\begin{array}{c}\text { Kareler } \\
\text { Toplamı }\end{array}$ & Df & $\begin{array}{c}\text { Ort. Kareler } \\
\text { Değeri }\end{array}$ & F & Sig. \\
\hline \multirow{2}{*}{1} & Regresyon & 104,540 & 1 & 104,540 & 73,139 &, $000^{\mathrm{b}}$ \\
\cline { 2 - 7 } & Artık Değer & 2316,950 & 1621 & 1,429 & & \\
\cline { 2 - 7 } & Toplam & 2421,490 & 1622 & & & \\
\hline
\end{tabular}

a. Bağımlı Değişken: Satın Alma Niyeti

b. Sabit Değişken: Sosyal Medya Kullanımı

Tablo 7' de görüldüğü üzere sosyal medya kullanımı ile tatil satın alma niyeti arasındaki ilişki için hesaplanan değer $\left(R=0,043^{* *}\right)$ istatistiksel olarak anlamlı bulunmuştur $(p<0,01)$.

Tablo 8. Sosyal Medya Kullanımı ile Kişinin Tatil Satın Alma Niyeti Arasındaki İlişkiye Ait Regresyon Katsayıları

\begin{tabular}{|c|c|c|c|c|c|c|}
\hline & \multirow[t]{2}{*}{ Model } & \multicolumn{2}{|c|}{$\begin{array}{c}\text { Standardize Edilmemiş } \\
\text { Katsayılar }\end{array}$} & \multirow{2}{*}{$\begin{array}{c}\begin{array}{c}\text { Standardizde Edilmiş } \\
\text { Katsayılar }\end{array} \\
\text { Beta }\end{array}$} & \multirow[t]{2}{*}{$\mathbf{t}$} & \multirow[t]{2}{*}{ Sig. } \\
\hline & & B & Std. Hata & & & \\
\hline \multirow{2}{*}{1} & \multirow{2}{*}{$\begin{array}{l}\text { (Sabit) Sosyal } \\
\text { Medya } \\
\text { Kullanımı }\end{array}$} & 1,873 & 0,105 & & 17,918 & ,000 \\
\hline & & 0,394 & 0,046 & 0,208 & 8,552 & ,000 \\
\hline
\end{tabular}

a. Bağımlı Değişken: Satın Alma Niyeti

Sosyal medya kullanımının tatil satın alma niyetine etkisini ortaya koymak için yapılan basit doğrusal regresyon analizi sonucunda (bkz. Tablo 8), sosyal medya kullanımı ile tatil satın alma niyeti arasında anlamlı bir ilişki $(0,394)$ olduğu gözlenmiş $\left(R=0,208, R^{2}=0,043\right)$ olup, sosyal medya kullanımının tatil satın alma niyetinin bir yordayıcısı olduğu görülmüştür ( $t=8,552, p<0,01)$. Bu bakış açısından yola çıkılarak $\mathrm{H}_{3}$ : "sosyal medya kullanımı kişinin tatil satın alma niyeti üzerinde etkilidir" hipotezi kabul edilmiştir. 
Sosyal medya kullanımı ile tüketici davranışları arasında anlamlı bir ilişki bulan bazı çalışmaların (Şahin vd., 2017; Xiang, Magnini ve Fesenmaier, 2015) yanı sıra bu çalışmada da sosyal medya kullanım yoğunluğunun kişilerin tatil satın alma niyetleri üzerinde anlamlı bir etkisi olduğu görülmüştür. Bunun nedeninin, kişilerin sosyal medyada gördükleri reklamlar veya takip ettikleri kişilerin yaptıkları tatil paylaşımları olabileceği söylenebilir.

\section{Gelişmeleri Kaçırma Korkusu Bağımsız, Tatil Satın Alma Niyeti Bağımlı Değişken Olmak Üzere Doğrusal Regresyon Analizi}

Araştırmaya katılanların GKK düzeyinin tatil satın alma niyeti üzerindeki etkisini ortaya koymak amacıyla basit doğrusal regresyon analizi yapılmıştır. Yapılan analize ait tablo aşağıda verilmiştir.

Tablo 9. Tatil Satın Alma Niyetinin GKK'ye Göre Yordanmasına İlişkin Regresyon Analizi Sonuçları

\begin{tabular}{ccccc}
\hline Model & $\mathbf{R}$ & $\mathbf{R}^{2}$ & Düzeltilmiş $\mathbf{R}^{2}$ & $\begin{array}{c}\text { Tahmini } \\
\text { Hata }\end{array}$ \\
\hline 1 & $0,257^{\mathrm{a}}$ & 0,066 & 0,065 & 1,18132 \\
\hline
\end{tabular}

a. Sabit Değişken: GKK

Tablo 9'a göre GKK ile satın alma niyeti değişkenleri arasında pozitif yönlü anlamlı bir ilişki $(\mathrm{R}=0,257)$ vardır. Ayrıca belirlilik katsayısı $\mathrm{R}^{2}=0,066$ olarak hesaplanmış olup tatil satın alma niyetinin \%65'inin GKK'ye bağlı olduğu söylenebilir $(\mathrm{p}<0,01)$.

Tablo 10. GKK ile Kişinin Tatil Satın Alma Niyeti Arasındaki İlişkinin Derecesini Gösteren Varyans (Anova) Analizi

\begin{tabular}{llccccc}
\hline \multicolumn{2}{l}{ Model } & $\begin{array}{c}\text { Kareler } \\
\text { Toplamı }\end{array}$ & Df & $\begin{array}{c}\text { Ort. Kareler } \\
\text { Değeri }\end{array}$ & F & Sig. \\
\hline \multirow{2}{*}{1 Regresyon } & 159,352 & 1 & 159,352 & 114,188 &, $000^{\mathrm{b}}$ \\
\cline { 2 - 7 } & Artık Değer & 2262,137 & 1621 & 1,396 & & \\
\cline { 2 - 7 } & Toplam & 2421,490 & 1622 & & & \\
\hline
\end{tabular}

a. Bağımlı Değişken: Satın Alma Niyeti

b. Sabit Değişken: GKK

Tablo 10 'da görüldüğü üzere GKK ile tatil satın alma niyeti arasındaki ilişki için hesaplanan değer $\left(R=0,066^{* *}\right)$ istatistiksel olarak anlamlı bulunmuştur $(\mathrm{p}<0,01)$.

Tablo 11. GKK ile Kişinin Tatil Satın Alma Niyeti Arasındaki İlişkiye Ait Regresyon Katsayıları

\begin{tabular}{|c|c|c|c|c|c|c|}
\hline & \multirow[t]{2}{*}{ Model } & \multicolumn{2}{|c|}{$\begin{array}{c}\text { Standardize Edilmemiş } \\
\text { Katsayılar }\end{array}$} & \multirow{2}{*}{$\begin{array}{c}\begin{array}{c}\text { Standardizde Edilmiş } \\
\text { Katsayılar }\end{array} \\
\text { Beta }\end{array}$} & \multirow[t]{2}{*}{$\mathbf{t}$} & \multirow[t]{2}{*}{ Sig. } \\
\hline & & B & Std. Hata & & & \\
\hline \multirow{2}{*}{1} & \multirow{2}{*}{ (Sabit) GKK } & 1,883 & 0,085 & & 22,275 & ,000 \\
\hline & & 0,391 & 0,037 & 0,257 & 10,686 & ,000 \\
\hline
\end{tabular}

a. Bağımlı Değişken: Satın Alma Niyeti

GKK'nin tatil satın alma niyetine etkisini ortaya koymak için yapılan basit doğrusal regresyon analizi sonucunda (bkz. Tablo 11), GKK ile tatil satın alma niyetine arasında anlamlı bir ilişki 
$(0,391)$ olduğu gözlenmiş $\left(R=0,257, R^{2}=0,066\right), G K K^{\prime}$ nin tatil satın alma niyetinin bir yordayıcısı olduğu görülmüştür $(t=10,686, p<0,01)$. Bu bakış açısından yola çıkılarak $\mathrm{H}_{4}$ : “Gelişmeleri kaçırma korkusu kişinin tatil satın alma niyeti üzerinde etkilidir" hipotezi kabul edilmiştir.

Literatürde yapılmış bazı çalışmalarda (Argan ve Tokay Argan, 2018; Argan vd., 2018; Aydın, 2018) GKK'nin tüketici davranışları üzerinde etkileri vardır. Bu çalışma sonuca göre de GKK'nin, kişilerin tatil satın alma niyeti üzerinde anlamlı bir etkisi olduğu görülmektedir. Bunun nedeninin; bireylerin, sosyal medyada takip ettikleri kişilerin tatil içerikli paylaşımlarda güzel anlar yaşadıklarına dair düşünceleri ve kendilerinin bu anları yaşamıyor olmalarının verdiği duygu durumunun tatil satın almayı istemelerine nedenS olduğu söylenebilir.

\section{TARTIŞMA, SONUÇ VE ÖNERILER}

İnternetle başlayan, sosyal medya ile artık hızına yetişmekte zorlanılan bir gelişim yaşanırken, değişen bilgi ve iletişim teknolojileriyle de en üst seviyeye ulaşan küreselleşmenin; toplumsal, ekonomik ve siyasi etkileriyle baş etmek ve bunlara uyum sağlayabilmek gittikçe zorlaşmaktadır. Web'in 2.0'dan 5.0'a, pazarlamanın 1.0' dan 4.0'a evrildiği; halkla ilişkiler, itibar yönetimi, reklam, vb.nin çevrimiçi yapılabilir olduğu bu çağda sosyal medyanın da etkisiyle yeni kavramlar ortaya çıkmıştır (Peltekoğlu, 2012:6). Bu kavramlardan biri de sosyal medya ile birlikte daha sık karşılaşılan GKK'dir. "Diğerleri sizsiz eğleniyor korkusu” (Przybylski vd., 2013) olarak ifade edilen GKK ile bireyler sürekli başkalarını takip etmekte ve bu takip etme alışkanlıklarının davranış haline gelmesi, araştırmanın konusu olan tatil satın alma niyetlerine de etki etmektedir. Bu bölümde, sosyal medyada GKK'nin kişinin tatil satın alma niyeti üzerindeki etkisini ortaya koymayı amaçlayan bu araştırmanın sonuçları ve literatürdeki diğer çalışmalarla benzerlikleri ve farklılıkları ortaya konulmaya çalışılmıştır. Ayrıca araştırma sonuçları ışığında araştırmacılara ve işletmelere yönelik öneriler sunulmuştur.

Baker vd.'nin (2016) çalışmalarına göre GKK ile sosyal medyada geçirilen zaman birbirleriyle pozitif olarak ilişkilidir. Bunun yanı sıra Michot vd.'nin (2015) çalışmalarında ise GKK ile sosyal medya kullanım yoğunluğu arasında orta düzeyde pozitif yönlü anlamlı bir ilişkinin $(\mathrm{r}=0,33$; p<0,01) varlığından söz edilmektedir. Swar ve Hameed'in (2017) çalışmalarında da yukarıda bahsedilen çalışmalara benzer olarak GKK ile SMB arasında pozitif yönlü bir ilişki olduğu görülmüştür. Konu ile ilgili başka bir çalışmada, (Przybylski vd., 2013), GKK'nin SMB için itici bir güç olabileceği sonucuna varılmıştır. Blackwell vd.'nin (2017) yaptığı çalışmada da GKK ile SMB arasında pozitif yönlü anlamlı bir ilişki olduğu görülmüştür. Yukarıda bahsedilen çalışmalarla aynı doğrultuda olmak üzere, yapılan bu araştırma sonucuna göre de Sosyal Medya Kullanımı ile GKK arasında pozitif yönlü anlamlı bir ilişki ( $H_{1}$ hipotezi) bulunmuştur ( $\mathrm{p}<0,01, \mathrm{R}=$ 0,633). Bahsedilen diğer çalışmalarla uyumlu olmasının yanısıra Scott ve Woods'un (2018) çalışmalarında, farklı olarak, GKK'nin, sosyal medyanın özellikle gece kullanım düzeyini artırdığı görülmüştür. Ayrıca Alt’ın (2017) çalışmasında GKK'nin SMB'yi açıklamada aracılık rolü oynadığı bulgusuna ulaşılmıştır.

Araştırma sonucuna göre, sosyal medya kullanımı ile GKK arasındaki ilişkinin tatil satın alma niyetini olumlu yönde etkilediği ( $H_{2}$ hipotezi) sonucuna ulaşılmıştır $(\mathrm{p}<0,01, \mathrm{R}=0,26)$. Yine bu araştırma sonucuna göre, sosyal medya kullanımının kişinin tatil satın alma niyeti üzerinde etkisi ( $H_{3}$ hipotezi) olduğu görülmüştür $\left(\mathrm{p}<0,01, \mathrm{R}^{2}=0,043\right)$. Bu hipotezle bağlantılı olarak, yapılan bir çalışmada (Şahin vd., 2017) sosyal medya pazarlaması ile tüketici satın alma davranışı arasında orta düzeyli anlamlı bir ilişki ortaya çıkarken başka bir çalışmada ise (Xiang, Magnini ve Fesenmaier, 2015) sosyal medyanın seyahat planlama üzerinde büyük bir etkisi olduğu sonucuna ulaşılmıştır. 
Yapılan bazı çalışmalar (Argan ve Tokay Argan, 2018; Argan vd., 2018; Aydın, 2018) GKK'nin tüketici davranışları üzerinde etkileri olduğunu ortaya koymuştur. Literatürde yer alan bu çalışmalarla uyumlu olarak araştırma sonucuna göre, GKK'nin kişinin tatil satın alma niyeti üzerinde etkisi (H4 hipotezi) olduğu görülmüştür $\left(\mathrm{p}<0,01, \mathrm{R}^{2}=0,066\right)$.

Literatür taraması ve araştırma sonuçları doğrultusunda, araştırmacılar ve işletmeler için geliştirilen önerilere aşağıda değinilmiştir.

Araştırmacılar İçin Öneriler:

Son zamanlarda birçok akademik çalışmaya konu olan sosyal medya ve GKK konularının (özellikle de GKK'nin), turizm alanında henüz yeni olduğu ifade edilebilir. Bu nedenle araştırmacılara aşağıdaki hususlar önerilmektedir:

Sosyal medya siteleri artık sosyal yaşamın bir parçası haline gelmiştir. İnsanlar kendileri hakkında diğerlerini bilgilendirmek istedikleri gibi arkadaşlarının neler yaptıkları hakkında da bilgilendirilmek istemektedirler. Sosyal medya ortamlarının popülerliği arttıkça, aşırı kullanımı ile ilgili sorunlar ortaya çıkmıştır (Blachnio ve Przepiorka, 2018). Araştırmacılar, sosyal medyanın aşırı kullanımının pazarlamaya dönük yararlarının yanı sıra, muhtemel potansiyel zararlarının da turistik tüketici davranışına etkilerinin ne yönde olduğuna dair çalışmalar yapabilirler (Örneğin; aşırı sosyal medya kullanımı, kişilerde yorgunluk, tükenmişlik yaratarak, kişilerin turistik davranışlarını değiştirebilir mi?).

Sosyal medya, ağızdan ağıza iletişim için çok faydalı bir araç olarak görülmektedir (Litvin vd., 2008). İleriki çalışmalarda ağızdan ağıza iletişimde sosyal medyanın rolünü ele alan turizm alanı ile ilgili bir konu çalışılabilir. Örneğin; sosyal medyada GKK'nin satın alma niyetine etkisinde ağızdan ağıza iletişimin rolü bir araştırma konusu olabilir.

Araştırmaya katılanların neredeyse hepsi $(\% 97,8)$ sosyal medyayı akıllı telefon üzerinden takip etmektedir. Bu durum akıllı telefonların yoğun olarak kullanıldığını göstermektedir. Zira kişiler sosyal medya kullanımının yanı sıra akıllı telefonları, başka fonksiyonları (internet, müzik, kamera, ...vb.) için de kullanmaktadırlar. Buradan hareketle akıllı telefon kullanımının turizmdeki yansımalarının (Örneğin; turistik ürün ve hizmetlerin talebinde ne kadar etkili olduğu gibi) ne şekilde olduğuna yönelik araştırmalar yapılabilir.

Ülkelerin turizm tanıtımı için kullandıkları sosyal medya hesapları incelenerek bir içerik analiz yapılabilir. Ayrıca içerik analizi sonucunda ne tür içeriklerin olduğu ve hangilerinin daha etkili olabileceği yönünde bir alan araştırması yapılabilir.

İşletmelere, turistlerin, sosyal medyadaki GKK'lerinin ne düzeyde olduğu sorulabilir. Sonuçlar göz önünde bulundurularak turistlerin tatil satın alma niyetlerini (turistik tüketim davranışlarını) nasıl etkileyebileceklerine dair bir araştırmanın yapılması önerilebilir.

GKK deneyimleri ile kaygı (Elhai vd., 2016), depresyon (Oberst vd., 2017) ve düşük yaşam doyumu (Przybylski vd., 2013) gibi bir dizi psikolojik eksiklik arasında pozitif yönde bir ilişki vardır. Tüketici davranışlarını etkileyen faktörlerden birisinin de psikolojik faktörler olduğu bilinmektedir. Araştırmacılar, GKK'nin hangi boyutta turistin tüketici davranışlarını etkilediğini ortaya koyan çalışmalar yapabilirler.

Birçok çalışmada GKK'nin farklı değişkenler arasında aracılık rolünün olduğu görülmüştür (Alt ve Boniel-Nissim, 2018; Elhai vd., 2018; Oberst, vd., 2017; Wolniewicz vd., 2018; Buglass vd., 2017; Wegmann vd., 2017; Beyens vd., 2016; Alt, 2015). Bu çalışmada bağımsız değişken olarak kullanılan GKK, turizme konu olan başka bir çalışmada aracılık rolü açısından GKK araştırılabilir. 
Yeşilay (www.yesilay.org.tr), bağımlılı̆̆ı, ciddi bir hastalık olarak ifade etmektedir. Sosyal medya bağımlılı̆̆ı olarak ifade edilen kavramda "bağımlılık" kelimesi kişilerin kendilerine hasta yakıştırmasının yapılması nedeniyle, bu alanda yapılan çalışmalara katılan kişiler için olumsuz bir durum yaratabileceği düşüncesiyle; "Sosyal Medya Bağımlılı̆̆ı" kavramı yerine "Sosyal Medya Kullanım Yoğunluğu" ifadesinin kullanılmasının daha uygun olacağı önerilmektedir. Araştırmacıların, çalışmalarında kullandıkları terimlerin, kişiler üzerindeki etkilerini anlamaya yönelik bir çalışma yapabilecekleri ve ayrıca bundan sonraki "sosyal medya bağımlılığı" çalışmalarında yukarıda bahsedilen hususu göz önünde bulundurmaları önerilebilir.

İşletmeler İçin Öneriler:

$\mathrm{Bu}$ araştırma sonucundan da anlaşılacağı üzere sosyal medyada GKK'nin tatil satın alma niyeti üzerinde etkisi olduğu görülmektedir. Bu nedenle işletmelerin sosyal medya kullanımına ağırlık vermeleri gerekmektedir. İşletmeler için aşağıdaki önerilerde bulunulabilir:

Sosyal medya üzerinden gerçekleştirilen pazarlama faaliyetleri işletmelerin hem maliyetlerini düşürmekte hem de tüketicilerin her an ve her yerden işletmelere ulaşmalarını sağlayabilmektedir (Bayram ve Şahbaz, 2012). İşletmelerin kişilere sunduğu seyahat öncesi deneyim için hazırlanan sanal turlar, videolar, önerilen güzergahlar ve daha önceki tüketicilerin deneyimlerine ait paylaşımları, potansiyel tüketiciler referans teşkil etmektedir (Gretzel vd., 2011). Buradan hareketle işletme ile ilgili bir web sitesi/sosyal medya hesabının mutlaka olmasına dikkat edilmelidir. Yoksa hemen açılması, var ise de etkinliği ve sürekliliğinin sağlanması önerilmektedir.

Ülkemizde insanlar (56,03 milyon kişi) çoğunlukla interneti, akıllı telefonlar üzerinden takip etmektedirler (Kemp, 2019). Bunun bir yansiması olarak da sosyal medya, banka, oyun, ... vb. gibi uygulamaları akıllı telefonlarına yükleyerek onlara daha kısa sürede ve kolaylıkla erişebilmekteler. İşletmeler de sosyal medya hesabı veya web sitesi ile yetinmeyerek akıllı telefonlara yüklenebilecek mobil uygulamalar aracılığıyla daha hızlı ve istenilen her an GKK'yi azaltabilecek (diğerlerinin neler yaptıkları) bilgilere ulaşılabilme imkânı yaratabilirler. Zira GKK'nin, akıllı telefonların aşırı kullanımına neden olmasının (Elhai vd., 2018; Wolniewicz vd., 2018) bu amaca bir nevi hizmet ettiği ifade edilebilir.

İşletmeler GKK'nin azaltılması yönünde mobil bir uygulama geliştirirken; aynı uygulamayı yükleyen kişilerin; "kim", "ne zaman", "markanın hangi tesisinde tatillerini geçirecekleri" vb. bilgileri; bunun yanı sıra tesiste geçirilen özel anlara ait paylaşımların da uygulama üzerinden takip edilmesine imkân sağlayan eklentiler yapabilirler.

Tatilini sosyal medyadan paylaşan kişileri takipte olanlar, kişinin nereye gittiğini soramayabilirler. Belki de çok beğendikleri ve kendilerinin de orada bulunmak istedikleri bir yer hakkında bilgi almak isteyebilirler. Bu nedenle kişiler tatil yerinden konum bildirmeye (Checkin) teşvik edilmelidir. Böylece sosyal medyada takip edilen kişinin hangi destinasyonda olduğu anlaşıldıktan sonra araştırma yapılabilmesine imkân tanınmış olur.

Tüketicilerin büyük bir kısmının tatil planı yaparken, başkalarının düşünceleri ve deneyimleri sonucunda elde ettikleri tatminin paylaşılmasını daha fazla önemsedikleri (Xiang vd., 2015) unutulmamalıdır. Bu noktada ağızdan ağıza iletişim önem arz etmektedir. Bunun yanı sıra işletmeler sosyal medya uygulamaları aracilığıyla da tutundurma faaliyetlerini gerçekleştirebilirler. Daha önce yapılan çalışmalarda (Bieger ve Laesser, 2000; Özyıldırım ve Koçoğlu, 2019) kişilerin, tatil satın alma kararı vermeden önce diğer insanların deneyim ve tecrübelerinden yararlanmalarının dışında, tatil yeri ile ilgili olarak medyada çıkan reklamlardan da etkilendikleri sonucuna ulaşılmıştır. Buradan hareketle kişilerin tatil deneyimleri ile ilgili yorum yapmaları ve görüşlerini paylaşmaları sağlanabilir. 
Turistler satın alma sonrasında internet teknolojilerini; turizm deneyimlerini diğer kişilerle paylaşmakla birlikte mekânlar, ilgi çekici yerler, ürün / hizmet sağlayıcılarla yakın ilişkiler kurmayı sağlamak amacıyla da kullanırlar (Gretzel vd., 2011). Isşletmelerin, bu amaçla işletmeyle iletişime geçmek isteyebilecek turistlerin varlığını bilmeleri ve iletişimi güçlendirmek için uygun sosyal medya ağlarını kullanmalarının faydalı olacağı düşünülmektedir.

$\% 90$ 'dan daha fazla tüketici, tanıdıkları insanların bir ürün ya da hizmet hakkındaki yorumlarına güvenmektedir (Hossain vd., 2017). İşletmeden memnun kalındığı takdirde müşterilerin olumlu düşüncelerini paylaşmaları teşvik edilebilir.

Satın alma sonrasında memnun olmayan mutsuz müşterinin büyük bir kısmı ürün hakkındaki şikayetlerini işletmeye anlatmamaktadır (Kotler ve Armstrong, 2011:154). Bu sebeple, işletmelerin müşteri memnuniyetlerini düzenli olarak ölçebilecekleri ve şikayetlerini işletmeye hızlıca iletmelerini teşvik eden bir sistem kurulabilir. Böylece sosyal medya kullanılarak şikayetlerin alınması ve geri dönütlerin sağlanması kolaylaşabilir.

Yapılan literatür taraması sonucunda sosyal medyanın gücünün (Hazar, 2011; Işık ve Topbaş, 2015; Kırık vd., 2015) ne denli büyük olduğu ortaya çıkmışır. Chan ve Guillet'in (2011) çalışmasına göre otellerin en çok kullandıkları sosyal medya hesapları Facebook ve Twitter'dır. Turistik işletmeler de sosyal medyada yerlerini alırken rakiplerinin hangi sosyal medya hesaplarını daha aktif olarak kullandıklarını tespit ederek onları takip edebilir (kıyaslama/benchmarking) ve yaptıklarından haberdar olabilirler. Böylece kendi eksikliklerini kıyaslayabilme olanağı bulabilirler.

Otellerin web sitelerinde paylaştıkları içerikler ve resimlerin gerçekçiliği müşterilerin davranışlarının önemli birer belirleyicisidir. Buna göre web'deki davranışlar, davranışsal niyetlerin çok güçlü bir tahmin edicisi durumundadır (Jeong ve Choi, 2005). Bu nedenle işletmelerin sosyal medyada yaptıkları fotoğraf, video ve içerik paylaşımlarının gerçekleri yansitmasına olabildiğince dikkat etmeleri önerilmektedir.

Köşk ve Gürbüz'ün (2017) çalışmasında; tatil ihtiyacı ve bilgi toplama, tatil süresi planlama ve tatile çıkma kararı ve hazırlık aşamalarında 15-24 yaş arası gençlerin etkilerinin oldukça yüksek olduğu görülmektedir. Buna göre gençlerin ailelerin tatil karar verme sürecinde önemli belirleyici rolleri olduğu söylenebilir. Başka bir çalışmada ise (Aymankuy ve Ceylan, 2013) özellikle 13 ve üzeri yaş grubuna dahil çocukların tatil satın alma karar sürecine (Tatil kararının verilmesinde, tatil bölgesinin belirlenmesinde, tatil yapılacak otelin seçiminde) karar verici olarak aktif bir şekilde katıldıkları sonucuna ulaşılmıştır. GKK sendromunun en çok Z kuşağında (2000 yılından sonra doğanlar (Seymen, 2017) görüldüğü de göz önüne alındığında (Yavuz, 2015) işletmelerin, karar verici durumunda bulunan yetişkinlere yapacakları reklam ve tanıtımların yanı sıra 13 yaş ve üzerindeki gençlere yönelik de pazarlama çabalarına yönelmeleri önerilebilir.

Sosyal medya üzerinden seyahat planlama özellikle $Y$ kuşağı arasında oldukça yaygındır (Xiang, Magnini ve Fesenmaier, 2015). İşletmelerin, sosyal medya üzerinden yaptıkları reklamlarda $Y$ kuşağının ilgisini çeken içeriklere daha fazla yer verilmesi önerilebilir.

Yapılan bir araştırma (Çabuk vd., 2013), olumlu bir kurum kimliği oluşturmanın (Kulaktan kulağa iletişimde başarılı olma, basında olumsuz haberlere konu olmama ve pazarlama iletişimi yöntemlerinden aktif bir şekilde faydalanma) müşterilerin gelecekte aynı kurumu tercih etmesi açısından etkili olduğunu ortaya koymaktadır. İşletmeler için en etkin halkla ilişkiler faaliyetlerinin yürütüldüğü ortamın sosyal ağlar olduğu ve onu etkin bir şekilde kullanmanın işletmelere büyük yarar sağlayacağı söylenebilir.

Temel ihtiyaç doyumu düşük olan bireyler, sosyal medyayı; genellikle sosyal yetkinliği geliştirmek için başkalarıyla bağlantı kurabilecekleri bir platform olarak ve sosyal bağları 
derinleştirmek için bir fırsat olarak algılarlar (Przybylski vd, 2013). Bu bireylerin, tatil planı yaparken seyahat acenteleri ya da diğer geleneksel araçları kullanmak yerine sosyal medyadan daha fazla etkilenebilecekleri düşünülebilir. Buradan yola çıkılarak işletmelerin ellerinde bulunan bu büyük gücü etkili bir şekilde kullanabilmek için profesyonel destek almalarının faydalı olacağı söylenebilir.

\section{KAYNAKÇA}

Abel, J. P., Buff, C. L. and Burr, S. A. (2016). Social Media and the Fear of Missing Out: Scale Development and Assessment, Journal of Business \& Economics Research, 14 (1): 33-43.

Alalwan, A. A. (2018). Investigating the Impact of Social Media Advertising Features on Customer Purchase Intention, International Journal of Information Management, 42: 65-77.

Al-Menayes, J. (2016). The Fear of Missing Out Scale: Validation of The Arabic Version and Correlation with Social Media Addiction, International Journal of Applied Psychology, 6(2): 41-46.

Alt, D. (2015). College Students' Academic Motivation, Media Engagement and Fear of Missing Out, Computers in Human Behavior, 49: 111-119.

Alt, D. (2017). Students' Social Media Engagement and Fear of Missing Out (FoMO) in a Diverse Classroom, J Comput High Educ, 29:388-410.

Alt, D. (2018). Students' Wellbeing, Fear of Missing Out, and Social Media Engagement for Leisure in Higher Education Learning Environments, Current Psychology, 37(1): 128-138

Alt, D. and Boniel-Nissim, M. (2018). Links Between Adolescents' Deep and Surface Learning Approaches, Problematic Internet Use, and Fear of Missing Out (FoMO), Internet Interventions, 13: 30-39.

Argan, M. ve Tokay Argan, M. (2018). Fomsumerism: A Theoretical Framework, International Journal of Marketing Studies, 10(2): 109-117.

Argan, M., Tokay Argan, M. ve İpek, G. (2018). I Wish I Were! Anatomy of A Fomsumer - Keşke Olsaydım! Bir FoMO Tüketicinin (Fomsumer) Anatomisi, İnternet Uygulamaları ve Yönetimi, 9 (1): 43-57.

Asur, S., and Huberman, B. A. (2010, August). Predicting the Future with Social Media, IEEE/WIC/ACM International Conference on Web Intelligence and Intelligent Agent Technology-Vol. 01 pp.492-499.

Aydın, H. (2018). Sosyal Medya Trendi Olan FoMO'nun Pazarlama Alanında Kullanımı Üzerine Literatür Taraması, İzmir Katip Çelebi Üniversitesi İktisadi ve İdari Bilimler Fakültesi Dergisi, 1(1): 19.

Aymankuy, Y. ve Ceylan, U. (2013-Bahar). Ailelerin Turistik Ürün Satın Alma Karar Sürecinde Çocukların Rolü (Yerli Turistler Üzerinde Bir Araştırma), Elektronik Sosyal Bilimler Dergisi, 12(45): 105-122.

Baban, E. (2012). Mc Luhan ve Baudrillard'ın Penceresinden Sosyal Medyanın Etkisi: İfadenin Esareti, Gözetlenen Toplum ve Kayıp Kimlik Sendromu, (Editörler) Kara, T. ve Özgen, E.: Sosyal Medya Akademi. İstanbul. Beta Yayıncilı.

Baker, Z. G., Krieger, H. and LeRoy, A. S. (2016). Fear of Missing Out: Relationship with Depression, Mindfulness, and Physical Symptoms, American Psychological Association, 2(3): 275282. 
Bayram, A. T. ve Şahbaz, R. P. (2012). Turizm İşletmelerinde Sosyal Medya Kullanımına Örnekler. 13. Ulusal Turizm Kongresi 6-9 Aralk 2012 Antalya, 353-362.

Beyens, I., Frison, E. and Eggermont, S. (2016). I don't Want to Miss a Thing: Adolescents' Fear of Missing Out and Its Relationship to Adolescents' Social Needs, Facebook Use, and Facebook Related Stress, Computers in Human Behavior, 64: 1-8.

Bieger, T. and Laesser, C. (2000). Segmenting Travel Situations on the Basis of Motivation and Information-Collection by the Traveller. The Tourist Review, 55(2): 54-64.

Blachnio, A. and Przepiorka, A. (2018). Facebook Intrusion, Fear of Missing Out, Narcissism, and Life Satisfaction: A Cross-Sectional Study, Psychiatry Research, 259: 514-519.

Blachnio, A., Przepiorka, A., Durak, E. S., Durak, M. and Sherstyuk, L. (2017). The Role of Personality Traits in Facebook and Internet Addictions: A Study on Polish, Turkish, and Ukrainian Samples, Computers in Human Behvior, 68: 269-275.

Blackwell, D., Leaman, C., Tramposch, R., Osborne, C. and Liss M. (2017). Extraversion, Neuroticism, Attachment Style and Fear of Missing Out as Predictors of Social Media Use and Addiction, Personality and Individual Differences, 116: 69-72.

Boyd, D. M. and Ellison, N. B. (2008). Social Network Sites: Definition, History, and Scholarship. Journal of Computer-Mediated Communication, 13: 210-230.

Buglass, S. L., Binder, J. F., Betts, L. R. and Underwood, J. D.M. (2017). Motivators of Online Vulnerability: The Impact of Social Network Site Use and FoMO, Computers in Human Behavior, 66: 248-255.

Casale, S., Rugai, L. and Fioravanti, G. (2018). Exploring the Role of Positive Metacognitions in Explaining the Association Between the Fear of Missing Out and Social Media Addiction, Addictive Behaviors, 85: 83-87.

Chan, N. L. and Guillet, B. D. (2011). Investigation of Social Media Marketing: How Does the Hotel Industry in Hong Kong Perform in Marketing on Social Media Websites?, Journal of Travel and Tourism Marketing, 28:345-368.

Classen, B. (2018). Social Media Engagement, The Fear of Missing OUT, AND PSYchosocial Correlates: A Mixed Methods Study (Doctoral dissertation, Auckland University of Technology).

Coşkun, R., Altunışık, R., Bayraktaroğlu, S. ve Yıldırım, E. (2015). Sosyal Bilimlerde Araştırma Yöntemleri. (8. Bask1). Sakarya: Sakarya Kitabevi.

Çabuk, S., Nakıboğlu, B. ve Canoğlu, M. (2013). Algılanan Otel İmajı ve Hizmet Kalitesi ile Tekrar Satın Alma Niyeti Arasındaki İlişkiler, Anatolia: Turizm Araştırmaları Dergisi, 24(1): 96-108.

Dhir, A., Yossatorn, Y., Kaur, P. and Chen, S. (2018). Online Social Media Fatigue and Psychological Wellbeing-A Study of Compulsive Use, Fear of Missing Out, Fatigue, Anxiety and Depression, International Journal of Information Management, 40: 141-152.

Doster, L. (2013). Fear of Missing Out: Is Voyeurism The Real Motive Behind Teen Consumption of Social Media?, European Advances in Consumer Research, 10: 146-147.

Dykman, A. (2012, March 21). "The Fear of Missing Out." [Online] https://www.forbes.com/sites/moneybuilder/2012/03/21/the-fear-of-missing-out/\#2a60136646bd [Erişim Tarihi: 14.11.2018]. 
Elhai, J. D., Levine, J. C., Alghraibeh, A. M., Alafnan, A. A., Aldraiweesh, A. A. and Hall, B. J. (2018). Fear of Missing Out: Testing Relationship with Negative Affectivity, Online Social Engagement, and Problematic Smartphone Use, Computers in Human Behavior, 89: 289-298.

Elhai, J. D., Levine, J. C., Dvorak, R. D. and Hall, B. J. (2016). Fear of Missing Out, Need for Touch, Anxiety and Depression are Related to Problematic Smartphone Use, Computers in Human Behavior, 63: 509-516.

Gil, F., Chamarro, A. and Oberst, U. (2015). Addiction to Online Social Networks: A Question of "Fear of Missing Out"?, 2nd International Conference on Behavioral Addictions March 16-18, 2015 Budapest, Hungary. Journal of Behavioral Addictions 4 (Suppl. 1), 1-66.

Gretzel, U., Fesenmaier, D. R. and O'Leary, J. T. (2011). The Transformation of Consumer Behaviour, In Buhalis, D. and Costa, C. (Eds) Tourism Business Frontiers. NY:Routledge pp.7-16.

Hazar, M. (2011). Sosyal Medya Bağımlılığı-Bir Alan Çalışması, İletişim Kuram ve Araştırma Dergisi, 32:151-176.

Hodkinson, C. (2016). Fear of Missing Out (FOMO) Marketing Appeals: A Conceptual Model, Journal of Marketing Communications:1-24.

Hossain, Md. M., Kabir, S. and Rezvi, R. I. (2017). Influence of Word of Mouth on Consumer Buying Decision: Evidence from Bangladesh Market, European Journal of Business and Management, 9(12): 38-45.

https://www.yesilay.org.tr/tr/bagimlilik/bagimlilik-nedir [Erişim Tarihi: 31.03.2019].

Işık, U., Topbaş, H. (2015). Facebook ve Bağımlılık: Medya Bağımlılığı Araştırması, International Journal of Social Science, 38: 319-336.

Jeong, M. and Choi, J. (2005). Effects of Picture Presentations on Customers' Behavioral Intentions on the Web, Journal of Travel \& Tourism Marketing, 17(2-3): 193-204.

Kemp, S. (30 January 2019). [Online] https://wearesocial.com/blog/2019/01/digital-2019-globalinternet-use-accelerates [Erişim Tarihi: 16.03.2019].

Kırık, A. M., Arslan, A., Çetinkaya, A. and Gül, M. (2015). A Quantitative Research on The Level of Social Media Addiction Among Young People in Turkey, International Journal of Science Culture and Sport, 3 (3): 2148-1148.

Kotler, P. and Armstrong, G. (2011). Principles of Marketing, (14th ed.) New Jersey: Prentice Hall.

Köşk, Ü. ve Gürbüz, A. (2017). Ailelerin Tatil Karar Sürecine Gençlerin Etkileri: Ankara İli Örneği. Journal of History Culture and Art Research, 6(3): 630-649. doi:http://dx.doi.org/10.7596/taksad.v6i3.912)

Litvin, S. W., Goldsmith, R. E. and Pan, B. (2008). Electronic Word-of-Mouth in Hospitality and Tourism Management, Tourism Management, 29: 458-468.

Michot, D., Blancot, C. and Munoz, B. B. B. (2015). Relationship Between Fear of Missing Out and Social Media Engagement in a French Population Sample. [Online] http://www.spotpink.com/spotpink/wp-content/uploads/Michot-Blancot-Bourdon-BaronMunoz-2016-VF.pdf [Erişim Tarihi: 31.01.2019].

Oberst, U., Wegmann, E., Stodt, B., Brand, M. and Chamarro, A. (2017). Negative Consequences from Heavy Social Networking in Adolescents: The Mediating Role of Fear of Missing Out. Journal of Adolescence, 55: 51-60. 
Osatuyi, B. and Turel, O. (2018). Tug of War Between Social Self-Regulation and Habit: Explaining the Experience of Momentary Social Media Addiction Symptoms, Computers in Human Behavior, 85: 95-105.

Özyıldırım, A. ve Koçoğlu, C. M. (2019). Tatil Satın Alma Kararını Etkileyen Faktörler: Kocaeli'ndeki Çağrı Merkezi Operatörleri Üzerine Bir Araştırma, Karabük Üniversitesi Sosyal Bilimler Enstitüsü Dergisi,9(1): 189-209.

Pavlou, P. A. and Gefen, D. (March-2004). Building Effective Online Marketplaces with Institution-Based Trust, Information Systems Research, 15(1), 37-59.

Peltekoğlu, F. B. (2012). Sosyal Medya Sosyal Değişim, T. Kara ve E. Özgen (Editörler). Sosyal Medya Akademi. İstanbul. Beta Yayıncilı.

Polat, D. (2016). Sosyal Medya ile Başım Dertte Ne Seninle Ne Sensiz, İstanbul: Yediveren Yayınları.

Przybylski, A. K., Murayama, K., DeHaan, C. R. and Gladwell, V. (2013). Motivational, Emotional, and Behavioral Correlates of Fear of Missing Out, Computers in Human Behavior, 29: 1841-1848.

Scott, H. and Woods, H. C. (2018). Fear of Missing Out and Sleep: Cognitive Behavioural Factors in Adolescents' Nighttime Social Media Use, Journal of Adolescence, 68: 61-65.

Seymen, A. F. (Kış-2017). Y ve Z Kuşak İnsanı Özelliklerinin Milli Eğitim Bakanlığı 2014-2019 Stratejik Programı ve TÜBİTAK Vizyon 2023 Öngörüleri ile İlişkilendirilmesi, Kent Kültürü ve Yönetimi Hakemli Elektronik Dergi, 10(4): 467-489.

Stead, H. and Bibby, P. A. (2017). Personality, Fear of Missing Out and Problematic Internet Use and Their Relationship to Subjective Well-Being, Computers in Human Behavior, 76: 534-540.

Swar, B. and Hameed, T. (2017). Fear of Missing Out, Social Media Engagement, Smartphone Addiction and Distraction: Moderating Role of Self-Help Mobile Apps-Based Interventions in the Youth. Proceedings of the 10th International Joint Conference on Biomedical Engineering Systems and Technologies (BIOSTEC 2017), 5: 139-146.

Şahin, C. ve Yağcı, M. (Nisan-2017). Sosyal Medya Bağımlılı̆̆ı Ölçeği-Yetişkin Formu: Geçerlilik ve Güvenirlik Çalışması, Ahi Evran Üniversitesi Kırşehir Ĕ̆itim Fakültesi Dergisi (KEFAD), 18(1): 523-538.

Şahin, E., Çağlıyan, V., ve Başer, H. H. (2017). Sosyal Medya Pazarlamasının Tüketici Satın Alma Davranışına Etkisi: Selçuk Üniversitesi İ̈BF Örneği, Ömer Halisdemir Üniversitesi İktisadi ve İdari Bilimler Fakültesi Dergisi, 10(4): 67-86.

Tien, D. H., Rivas, A. A. A. and Liao, Y. K. (2018). Examining the Influence of Customer-toCustomer Electronic Word-of-Mouth on Purchase Intention in Social Networking Sites, Asia Pacific Management Review: 1-12.

Toprak, A., Yıldırım, A., Aygül, E., Binark, M., Börekçi, S. ve Çomu, T. (2009). Toplumsal Paylaşım A ̆̆g Facebook: "Görülüyorum Öyleyse Varım", İstanbul: Kalkedon Yayınları.

Wang, X., Yu, C. and Wei, Y. (2012). Social Media Peer Communication and Impacts on Purchase Intentions: A Consumer Socialization Framework. Journal of Interactive Marketing, 26(4): 198-208.

Wegmann, E., Oberst, U., Stodt, B. and Brand, M. (2017). Online-Specific Fear of Missing Out and Internet-Use Expectancies Contribute to Symptoms of Internet-Communication Disorder, Addictive Behaviors Reports, 5: 33-42. 
Wolniewicz, C. A., Tiamiyu, M.F., Weeks, J. W. and Elhai, J. D. (2018) Problematic Smartphone Use and Relations with Negative Affect, Fear of Missing Out, and Fear of Negative and Positive Evaluation, Psychiatry Research, 262: 618-623.

Xiang, Z., Magnini, V. P. and Fesenmaier, D. R. (January 2015). Information Technology and Consumer Behavior in Travel and Tourism: Insights from Travel Planning Using the Internet, Journal of Retailing and Consumer Services, 22: 244-249.

Xiang, Z., Wang, D., O'Leary, J. T. and Fesenmaier, D. R. (2014). Adapting to the Internet: Trends in Travelers' Use of the Web for Trip Planning, Journal of Travel Research, 54(4): 511-527.

Yavuz, M. (15 Eylül 2015). Gelişmeleri Kaçırma Korkusu FOMO, Gençleri Esir Aldı, [Online] http://www.reemnp.com/gelismeleri-kacirma-korkusu-fomo-gencleri-esir-aldi [Erişim Tarihi: 04.11.2017]

Yin, C. Y., Poon, P. and Su, J. L. (2017). Yesterday Once More? Autobiographical Memory Evocation Effects on Tourists' Post-Travel Purchase Intentions Toward Destination Products, Tourism Management, 61: 263-274.

Zhao, X. R., Wang, L., Guo, X. and Law, R. (2015). The Influence of Online Reviews to Online Hotel Booking Intentions, International of Contemporary Hospitality Management, 27(6): 1343-1364. 